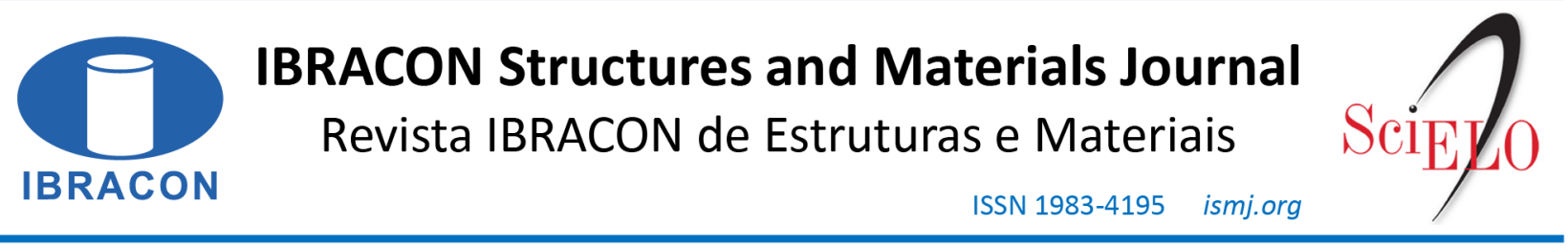

ORIGINAL ARTICLE

\title{
Strength optimization of reactive powder concrete
}

\section{Otimização da resistência mecânica de concretos de pós reativos}

\author{
Abrahão Bernardo Rohden ${ }^{\mathrm{a}}$ (D) \\ Ana Paula Kirchheim ${ }^{\mathrm{b}}$ (1) \\ Denise Dal Molin ${ }^{\mathrm{b}}$
}

${ }^{a}$ Fundação Universidade Regional de Blumenau - FURB, Departamento de Engenharia Civil, Blumenau, SC, Brasil

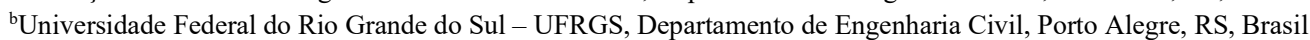

Received 11 November 2018 Accepted 17 Febuary 2020

\begin{abstract}
Recent reports on reactive powder concrete address important aspects regarding its performance. Several techniques are used to improve the design of such concretes. Ultra-high compressive strengths have been reported with the application of pre-setting pressure and autoclave curing. The objective of this work is to evaluate the use of very fine quartz powder to replace fine aggregate, nanosilica, and inorganic pigments to optimize mechanical properties of reactive powder concrete. The experimental work was developed in three distinct phases. In the first phase, mix-proportions of reactive powder concrete have been developed, considering different maximum aggregate sizes $(1.2,0.6,0.075$, and $0.045 \mathrm{~mm})$. In the second phase, the influence of nanosilica on the properties of reactive powder concrete was evaluated. In the third phase, the effect of the addition of yellow, green, orange, and blue inorganic pigments to the reactive powder concrete mix-design was evaluated. Results show that the maximum aggregate size influences the compressive strength of the reactive powder concrete. A decrease from $1.2 \mathrm{~mm}$ to $0.045 \mathrm{~mm}$ in the maximum aggregate size resulted in $156 \mathrm{MPa}$ increase in the compressive strength. The type of pigment did not significantly influence the compressive strength of the reactive powder concrete. The mix-proportion that resulted in the highest compressive strength (310.7 MPa) was designed using yellow pigment.
\end{abstract}

Keywords: powder-reactive concrete, quartz powder, inorganic pigments, nanosilica.

Resumo: Pesquisas acerca do concreto de pós reativo (CPR) têm abordado vários aspectos importantes sobre seu desempenho. São diversas as técnicas de aprimoramento empregadas na elaboração destes concretos. Com isso, resistências à compressão elevadas têm sido relatadas com a aplicação de tensões de pré-adensamento e cura em autoclave. O objetivo deste trabalho foi avaliar a aplicação de pó de quartzo em substituição ao agregado miúdo, de nanosílica e de pigmentos inorgânicos na otimização das propriedades mecânicas do CPR. $\mathrm{O}$ trabalho experimental foi desenvolvido em três fases. Na primeira foram dosados traços de CPR com agregados de diferentes dimensões máximas características $(1,2 ; 0,6 ; 0,075$ e $0,045 \mathrm{~mm})$. Na segunda fase avaliou-se a influência da nanosílica nas propriedades do CPR. Na terceira fase avaliou-se o efeito da adição de pigmento amarelo, verde, laranja e azul, todos inorgânicos, na dosagem de CPR. Como principais resultados, observou-se que a resistência à compressão do CPR é influenciada pela dimensão máxima característica do agregado. Ao passar a dimensão máxima do agregado de $1,2 \mathrm{~mm}$ para $0,045 \mathrm{~mm}$ à resistência a compressão do concreto aumentou $156 \mathrm{MPa}$. O tipo de pigmento empregado no CPR não influenciou à resistência a compressão de forma significativa. O traço de maior resistência foi dosado com pigmento amarelo e teve uma resistência média de $310,7 \mathrm{MPa}$.

Palavras-chave: concreto de pó-reativo, pó de quartzo, pigmentos inorgânicos, nanosílica.

How to cite: A. B. Rohden, A. P. Kirchheim, and D. Dal Molin, "Strength optimization of reactive powder concrete," Rev. IBRACON Estrut. Mater., vol. 13, no. 5, e13507, 2020, https://doi.org/10.1590/S1983-41952020000500007

Corresponding author: Abrahão Bernardo Rohden. E-mail: abrcivil@gmail.com

Financial support: The participation of APK was sponsored by CNPq (Brazilian National Council for Scientific and Technological Development) through the research fellowships PQ2017 303753/2017-0.

Conflict of interest: Nothing to declare. 


\section{INTRODUCTION}

The development of reactive powder concretes (RPC) can be achieved by applying some principles to the formulation, among which, the elimination of coarse aggregates, granular optimization, pressure application during casting, thermal treatment after hardening and incorporation of metallic microfibers [1], [2].

Techniques for granular optimization can be used to strengthen RCP mechanical performance and consistency. The fine aggregates most used in RCP are quartz aggregates and metallic aggregates, which present high mechanical strength. However, other aggregates of basaltic, granitic, and calcareous origin can also be used. In RCP, the aggregate is not a limiting factor of compressive strength; i.e. concretes with more than $200 \mathrm{MPa}$ can be produced using low strength aggregates such as limestone (83 MPa) [3].

RCP compositions have higher contents of supplementary cementitious materials (SCM) than standard highperformance concretes. Silica fume is the most used SCM in RCP. However, other SCMs such as fly ash, blast furnace slag, pulverized phosphorus slag, glass powder and recycled powder of ceramic bricks are also used to increase granular density [4]-[9]. Also, the improvement of the mixture performance in the fresh state [10] or the reduction in the superplasticizer [11], [12] and in the cement consumption [13] can be achieved using these materials. Other lines of research seek to improve RCP performance by incorporating nanoparticles like those of nanosilica and titanium dioxide [14].

For being composed of fines powders, RPC demands high energy to be mixed. The mixing method also influences the RPC characteristics. Hiremath and Yaragal [15] investigated the effect of the mixing speed $(25,50,100,125$, and $150 \mathrm{rpm})$ and time of mixture $(10,15,20,25$, and $30 \mathrm{~min})$ on fresh RPC characteristics. The authors verified that the mixture speed must be between 50 and $100 \mathrm{rpm}$, low speeds compromise the performance. On the other hand, high speeds showed high contents of air entrained. The time of mixture of $15 \mathrm{~min}$ showed better fluidity and strength characteristics than those of the others studied.

In conventional strength concretes (Class I), the application of thermal cure improves strength in the first ages but tends to reduce strength at 28 days and more. In the RPC, this condition is not observed, and the thermal cure presents far superior results, even at 28 days [16], [12].

RPCs with 200 MPa compressive strength can be mixed with fine quartz sand and quartz powder, and thermal treatment at $90^{\circ} \mathrm{C}$. The application of steel microfibers increases material ductility and its tensile strength. On the other hand, to obtain RPC with strength superior to $600 \mathrm{MPa}$, casting procedure with application of compression loads while fresh of around $50 \mathrm{MPa}$ is necessary, as well as thermal treatment at temperatures from $250^{\circ} \mathrm{C}$ to $400^{\circ} \mathrm{C}$ in an autoclave. The incorporation of metallic aggregates to replace quartz aggregates can further improve its mechanical performance [1].

The use of steel fibers increases the RPC ductility as well as its flexural strength and fracture energy [1]. Han et al. [17] pointed out that the use of stainless-steel fibers with diameters of $8 \mu \mathrm{m}$ and $20 \mu \mathrm{m}$ and the incorporation of $0.5 \%$ in volume significantly increased flexural strength and fracture energy, similar to what happens with steel fibers.

Ji et al. [18] investigated the effect of the content of steel fiber (1\%, 2\%, 3\%, and 4\%) on RPC crack resistance. According to the authors, the steel fiber content shows the most significant effect on RPC behavior concerning cracking. Other factors, like water/binder ratio or sand/binder ratio, are not so relevant. Also, according to the authors, $3 \%$ content of fiber in volume was the one that provided the best performance regarding cracks.

Pressure application in casting allows a substantial increase in compressive strength. Ipek et al. [19] studied the effect of the use of densification strain assisted by a piston specially developed for this purpose. The concretes studied received densification strains of 25,50,75,100, and $125 \mathrm{MPa}$. The higher compressive strength reached in the study was $475 \mathrm{MPa}$, which corresponded to $100 \mathrm{MPa}$ casting strain. In addition to the application of pressure in casting, the concretes received thermal treatment at $300^{\circ} \mathrm{C}$ for 12 hours. Aydin et al. [3] demonstrated that the strength increase could reach $130 \mathrm{MPa}$ when comparing a concrete cured simply in an autoclave (270 MPa) with a concrete pressed and cured in an autoclave (400 MPa).

In addition to compressive strength, other RPC properties are also improved with the application of the densification strain. Ipek et al. [20] studied the effect of the application of strain in RPC densification with six levels $(0,5,10,15$, 20, $25 \mathrm{MPa}$ ) assessing the flexural tensile strength and the fracture energy. For the lowest level of densification strain, an increase in flexural tensile strength was 34\%. Fracture energy, on the other side, increased in up to 3 times for the highest level of densification strain.

The application of autoclave curing has also been studied to improve RPC mechanical performance. Yazic1 et al. [21] determined the influence of pressure-temperature $\left(0 \mathrm{MPa}-20^{\circ} \mathrm{C} ; 1 \mathrm{MPa}-180^{\circ} \mathrm{C} ; 2 \mathrm{MPa}-210^{\circ} \mathrm{C}\right.$ and $\left.3 \mathrm{MPa}-235^{\circ} \mathrm{C}\right)$ and time of autoclave curing $(0 \mathrm{~h} ; 4 \mathrm{~h} ; 6 \mathrm{~h} ; 12 \mathrm{~h}$ and $24 \mathrm{~h})$ in their research. The authors observed that the RPC compressive strength increases significantly after the application of autoclave curing and that it occurs due many reactive components remain unreacted under the cure conditions at room temperature ( $0 \mathrm{MPa}$ - 
$20^{\circ} \mathrm{C}$ ). The authors also observed that there is a critical time (optimum) for each level of temperature-pressure applied. Mostofinejad et al. [22] reached a considerable increase (174\%) in RPC strength by using autoclave curing with temperatures between 125 and $220^{\circ} \mathrm{C}$. Zerb [23], on the other hand, investigated not only the time of autoclave curing but also the heating and cooling ramp. The author verified that autoclave curing time is the factor that has the most critical influence in compressive strength. The study also confirmed that autoclave treatment promoted the refining of pores smaller than $100 \mu \mathrm{m}$.

Other research is being developed to investigate the use of RPC in structural elements. RPC used in pillars improves the performance of the structural component to impacts as well as its shear strength [24]. Ni et al. [25], on the other hand, used RPC, with fibers, in the development of plates aiming the high ballistic performance.

The low porosity of RPC increases its durability, making it a material potentially appropriate for the storage of nuclear wastes. Matte and Moranville [26] simulated leaching in a recipient containing radioactive wastes during a lifespan of 300 to 500 years. The high contents of active silica avoid the leaching of calcium hydroxide, thus reducing porosity and increasing durability.

Considering all interesting possibilities of this type of concrete, the present work aimed to optimize an RPC composition through the choice of Brazilian aggregates, incorporation of nanosilica, and inorganic pigments, seeking to maximize mechanical performance. Fibers, densification loads, and autoclave curing were not used.

\section{MATERIALS AND EXPERIMENTAL PROGRAM}

Figure 1 presents the research development phases. First, a study was developed to identify the influence of the size of aggregate particles in RPC resistance, and the characterization of the elasticity modulus of the concretes. In Phase 2, the objective was to assess the feasibility of incorporating nanosilica to RPC as a strategy to increase its compressive strength. The test specimens produced in phase 2 were also tested for flexural strength. Finally, in phase 3 , the influence of the type of pigment in RPC strength was assessed.

PHASE 1 - Assessment of aggregate size influence in RPC compressive strength and elasticity modulus
Phase 2 - Assessment of nanosilica content influence

in RPC compressive and tensile strength
Phase 3 - Assessment of

pigment influence in RPC compressive strength

Figure 1. Research phases.

\subsection{Materials}

\subsubsection{Portland Cement}

Two types of Portland cements were used in the present study. The two first phases of the research were developed using CPV ARI (high early strength Portland cement). In the third phase, CPB 40 Portland cement was used. The pigment utilized to color the concrete in this phase presents a better result when white cement is used.

Table 1 presents the physical and chemical properties of the two cements utilized in this study. Figure 2 shows the particle size distributions of the two cements. The cements surface areas are equal, as well as their strength at 28 days. 
Table 1. Physical and chemical characteristics of the cements used (Source: the authors, 2020).

\begin{tabular}{|c|c|c|c|c|c|c|}
\hline \multicolumn{2}{|c|}{ Characteristics and properties } & Unit & $\begin{array}{l}\text { CP V } \\
\text { ARI }\end{array}$ & $\begin{array}{c}\text { Limits NBR } \\
5733\end{array}$ & CPB 40 & $\begin{array}{c}\text { Limits } \\
\text { NBR12989 }\end{array}$ \\
\hline \multicolumn{2}{|l|}{ Insoluble residues } & $\%$ & 1.0 & $1.0 \%$ & - & - \\
\hline \multicolumn{2}{|l|}{ Loss on ignition } & $\%$ & 3.30 & $<4.5$ & 9.81 & $\leq 12$ \\
\hline \multicolumn{2}{|c|}{ Magnesium oxide $(\mathrm{MgO})$} & $\%$ & 1.75 & $<6.5$ & 2.22 & $\leq 6.5$ \\
\hline \multicolumn{2}{|c|}{ Sulfur trioxide $\left(\mathrm{SO}_{3}\right)$} & $\%$ & 3.11 & $<3.5$ & 4.68 & $\leq 4$ \\
\hline \multicolumn{2}{|c|}{ Fineness (residue in the $75 \mu \mathrm{m}$ sieve) } & $\%$ & 1.5 & $<6.0$ & 1.88 & $\leq 12$ \\
\hline \multicolumn{2}{|c|}{ Setting start time } & $\min$. & 160 & $>60$ & 160 & $>60$ \\
\hline \multicolumn{2}{|c|}{ Setting end time } & $\min$. & 315 & $<600$ & 205 & $\leq 600$ \\
\hline \multicolumn{2}{|c|}{ Specific surface area (Blaine Method) } & $\mathrm{m}^{2} / \mathrm{kg}$ & 446.7 & $>300$ & 477.2 & - \\
\hline \multirow{4}{*}{ Compressive strength } & 1 day & $\mathrm{MPa}$ & 24.2 & $>14.0$ & - & - \\
\hline & 3 days & $\mathrm{MPa}$ & 35.5 & $>24$ & 33,7 & $\geq 15$ \\
\hline & 7 days & $\mathrm{MPa}$ & 41.0 & $>34$ & 39,8 & $\geq 25$ \\
\hline & 28 days & $\mathrm{MPa}$ & 50.9 & - & 48,0 & $\geq 40$ \\
\hline \multicolumn{2}{|c|}{ Specific mass (NBR NM 43) } & $\mathrm{g} / \mathrm{cm}^{3}$ & 3.15 & - & 2.90 & - \\
\hline
\end{tabular}

\subsubsection{Silica Fume}

The specific mass determined, according to NM 43 [27], was $2.20 \mathrm{~kg} / \mathrm{dm}^{3}$. The silica fume particle size distribution is shown in Figure 2. The average diameter determined, d50, was defined as $5.86 \mu \mathrm{m}$.

\subsubsection{Quartz powder}

Two types of quartz powder were used. One presents $50 \%$ of grains with a diameter below $11.08 \mu$ and $100 \%$ passing through the $45 \mu \mathrm{m}$ sieve, and 325 mesh. The second presents $50 \%$ of grains with a diameter below $22.87 \mu \mathrm{m}$ and $100 \%$ passing through the $75 \mu$ sieve, and this material is traded as 200 mesh. The particle size distribution of both quartz powders is presented in Figure 2. The specific mass determined, according to NM 43 [27], was $2.61 \mathrm{~g} / \mathrm{cm}^{3}$ for the two types of powder.

\subsubsection{Fine aggregate}

Two naturals sands were used. The specific mass determined, according to NM 43 [27], was $2.63 \mathrm{~g} / \mathrm{cm}^{3}$ for both sands. Figure 2 presents the particle size distribution for the two natural sands. The two samples show maximum characteristic dimensions of $1.20 \mathrm{~mm}$ and $0.60 \mathrm{~mm}$ and fineness modules of 2.64 and 1.23 , respectively.

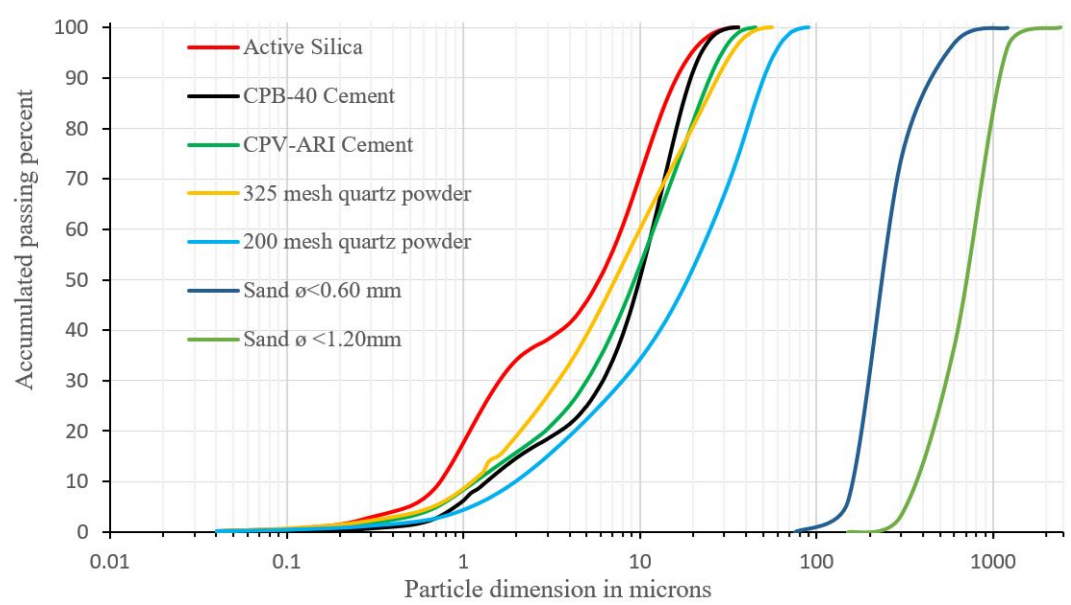

Figure 2. Particle size distribution of cement, active silica, quartz powder and fine aggregate particles. 


\subsubsection{Superplasticizer and superplasticizer with nanosilica}

Two chemical admixtures were used: a) one polycarboxylate-based superplaticizer (PCE) and, b) one polycarboxylate-based superplasticizer with nanosilica (PCE_N). The first PCE present, according to the manufacturer, the following technical characteristics: a) density from 1.067 to $1.107 \mathrm{~g} / \mathrm{cm}^{3}$; b) $\mathrm{pH}$ between 5 and 7 and; c) solid content between 38 and $40 \%$.

To assess the superplasticizer efficiency, its saturation point was determined using Part 2 of NBR 7681 [28] which presents the method for the determination of the melt flow index. The procedures for determination of the superplasticizer saturation point followed the recommendation of American standard ASTM C939 [29]. The test to measure the melt flow time and saturation time comprises the paste production; the passage of the mix through the cone; and the determination of its melt flow time.

Differently from conventional and high-performance concretes, in RPC mix proportion, the saturation point is not directly used to define the maxim chemical admixture content used in the mixture. In the mix proportion, superior contents of the chemical admixture saturation point is used due the high amount of powders. The criterion adopted to define the content of the superplasticizer was RPC workability. Formagini [30] described the experimental procedure adopted for the determination of granular packaging by water demand. This procedure starts with a mixture of dry materials, and, with water or superplasticizer increments, three states occur pendular, funicular, and capillary. The chemical admixture content was experimentally defined for the mixture to reach the capillary state. In the present work, the content of the superplasticizer adopted was $4.3 \%$ of the binder mass.

The second chemical admixture used in the study is a polycarboxylate based superplasticizer, in a liquid state, where nanosilica is dispersed. The manufacturer of this product does not inform the content of nanosilica present. The PCE_N specific mass is $1.06 \mathrm{~g} / \mathrm{cm}^{3}$. The chemical admixture content recommended by the nanosilica manufacturer for high strength concretes is up to $2 \%$. To verify whether the PCE and PCE_N are compatible with the materials, Marsh funnel test was used. The test followed the same procedures as those used to determine saturation point, however, in addition to cement $(2,000 \mathrm{~g})$, silica fume $(500 \mathrm{~g})$ was used. The water/cement ratio used was 0.23 . Figure 3 presents the results of the flowing times and the saturation point of the PCE. Table 2 shows flowing times measured for the different combinations of PCE_N and PCE.

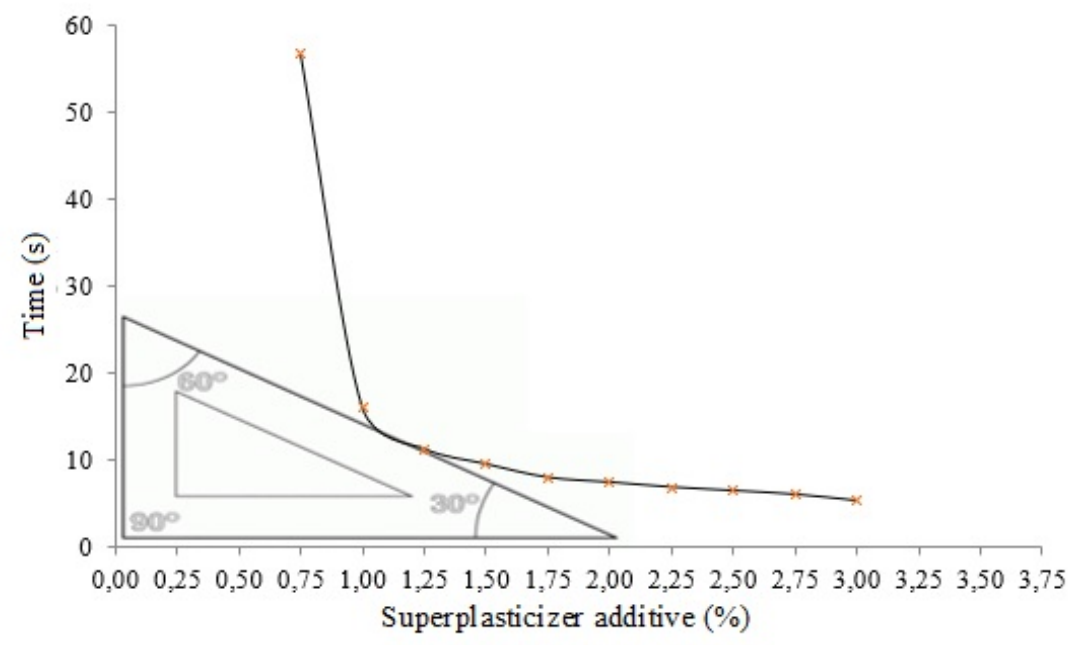

Figure 3. Graphic determination of the PCE saturation point for w/c ratio of 0.23 .

Table 2. Flowing time for different proportions of SP and SPN.

\begin{tabular}{cc}
\hline Composition & Flowing time (seconds) \\
\hline $0.0 \%$ SPN and $4.3 \%$ SP & 43.7 \\
\hline $2.0 \%$ SPN and $2.3 \%$ SP & 71.3 \\
\hline $3.0 \%$ SPN and $1.3 \%$ SP & 75.3 \\
\hline $4.3 \%$ SPN and $0.0 \%$ SP & 93.85 \\
\hline
\end{tabular}


As can be observed in Table 2, the flowing time increases with an increase in PCE_N percent. This fact indicates that the PCE is more efficient in the dispersion of fine particles.

\subsubsection{Inorganic pigments}

All pigments used in this work presented high fineness, superior to the $45 \mu$ sieve. The yellow pigment (Color Index 77492 ) used is composed of iron oxide $\left(\mathrm{Fe}_{2} \mathrm{O}_{3}\right)$ with a $4.7 \mathrm{~g} / \mathrm{cm}^{3}$ specific mass. The orange pigment (or light Brown Color Index 77491) used is also composed of iron oxide $\left(\mathrm{Fe}_{2} \mathrm{O}_{3}\right)$ with a $4.7 \mathrm{~g} / \mathrm{cm}^{3}$ specific mass. The blue pigment (Color Index 74160) was cobalt oxide $\left(\mathrm{Co}(\mathrm{Al}, \mathrm{Cr})_{2} \mathrm{O}_{4}\right)$, while the green pigment (Color Index 77492) was chromium oxide $\left(\mathrm{Cr}_{2} \mathrm{O}_{3}\right)$.

\subsection{Mix proportion evaluated}

Table 3 presents the mix proportion used in the research. The initial determination of the compositions was made by trial and error, before the development of this work. In the first phase, the influence of the aggregate particle size in RPC was studied. Eight compositions were prepared with two water/binder ratios and four compositions of powders. Water/binder ratios were 0.18 and 0.25 . The aggregate compositions, on the other hand, included sand with a maximum dimension of $1.2 \mathrm{~mm}$ and quartz powder; only sand with $0.66 \mathrm{~mm}$ dimension; only quartz powder with maximum $0.075 \mathrm{~mm}$ diameter; and only quartz powder with maximum dimensions characteristic of $0.045 \mathrm{~mm}$. Experimentally, it was not possible to prepare compositions with the two granulometry of the quartz powders with water/binder ration of 0.18 as occurred with the other combinations.

In Phase 2, PCE_N incorporation occurred instead of the PCE used in Phase 1. Contents of $0 \%, 2 \%, 3 \%$ and $4 \%$ were tested of substitution of PCE for PCE_N.

In the third Phase, the use of white cement (CPB 40) and different color pigments were assessed in RPC compressive strength. Eight composition from phase 1 were tested in in phase 3 . However, as the CPB 40 presents a specific mass smaller than that of cement CPVARI, correction in mass was made for the composition to give the same proportions in absolute volume. Yellow, blue, green, and orange pigments were tested. In all compositions, $2 \%$ entrained air volume was considered.

All compositions were mixed in a planetary mixer in $5 \mathrm{~L}$ container. The order of placement of materials was as follows: placement of the water, cement, and the superplasticizer. They were homogenized at a rotation speed of $65 \mathrm{rpm}$. Finally, the aggregate was incorporated into the mix. During the aggregate addition, the mixture speed was $125 \mathrm{rpm}$.

Table 3. Mix proportion of materials studied per phase $\left(\mathrm{kg} / \mathrm{m}^{3}\right)$.

\begin{tabular}{|c|c|c|c|c|c|c|c|c|c|c|c|c|c|c|c|c|}
\hline \multirow{2}{*}{ Materials } & \multicolumn{8}{|c|}{ Phase 1} & \multicolumn{4}{|c|}{ Phase 2} & \multicolumn{4}{|c|}{ Phase 3} \\
\hline & 1 & 2 & 3 & 4 & 5 & 6 & 7 & 8 & 9 & 10 & 11 & 12 & 13 & 14 & 15 & 16 \\
\hline CPV ARI & 874 & 820 & 874 & 820 & 874 & 820 & 820 & 820 & 820 & 819 & 819 & 819 & - & - & - & - \\
\hline CРВ 40 & - & - & - & - & - & - & - & - & - & - & - & - & 805 & 805 & 805 & 805 \\
\hline Active silica & 215 & 202 & 215 & 202 & 215 & 202 & 202 & 202 & 205 & 205 & 205 & 205 & 198 & 198 & 198 & 198 \\
\hline Water & 157 & 205 & 157 & 205 & 157 & 205 & 205 & 205 & 188 & 188 & 188 & 188 & 185 & 185 & 185 & 185 \\
\hline PCE & 26 & 24 & 26 & 24 & 26 & 24 & 24 & 24 & 35 & 19 & 11 & 0 & 24 & 24 & 24 & 24 \\
\hline PCE_N & - & - & - & - & - & - & - & - & - & 16 & 25 & 35 & - & - & - & - \\
\hline $\begin{array}{l}\text { Quartz powder } \\
\varnothing 0.045 \mathrm{~mm}\end{array}$ & 205 & 192 & - & - & - & - & - & 1,095 & 1,107 & 1,106 & 1,106 & 1,106 & 1,076 & 1,076 & 1,076 & 1,076 \\
\hline $\begin{array}{c}\text { Quartz powder } \\
\varnothing 0.075 \mathrm{~mm}\end{array}$ & - & - & - & - & - & - & 1,095 & - & - & - & - & - & - & - & - & - \\
\hline Sand $\varnothing 0.6 \mathrm{~mm}$ & - & - & - & - & 1,167 & 1,095 & - & - & - & - & - & - & - & - & - & - \\
\hline Sand $\varnothing 1.2 \mathrm{~mm}$ & 962 & 903 & 1,167 & 1,095 & - & - & - & - & - & - & - & - & - & - & - & - \\
\hline Yellow pigment & - & - & - & - & - & - & - & - & - & - & - & - & 60 & - & - & - \\
\hline Blue pigment & - & - & - & - & - & - & - & - & - & - & - & - & - & 60 & - & - \\
\hline Green pigment & - & - & - & - & - & - & - & - & - & - & - & - & - & - & 60 & - \\
\hline Orange pigment & - & - & - & - & - & - & - & - & - & - & - & - & - & - & - & 60 \\
\hline w/c ratio & 0.18 & 0.25 & 0.18 & 0.25 & 0.18 & 0.25 & 0.25 & 0.25 & 0.23 & 0.23 & 0.23 & 0.23 & 0.23 & 0.23 & 0.23 & 0.23 \\
\hline $\begin{array}{c}\text { Cement }+ \text { silica } \\
\text { fume } \\
\text { consumption } \\
\end{array}$ & 1,089 & 1,022 & 1,089 & 1,022 & 1,089 & 1,022 & 1,022 & 1,022 & 1,025 & 1,024 & 1,024 & 1,024 & 1,003 & 1,003 & 1,003 & 1,003 \\
\hline
\end{tabular}


After the mixture, 3 test specimens $(5 \times 10 \mathrm{~cm})$ of each composition were molded to determine compressive strength. The test specimens were demolded 24 hours later and were taken to 28 days of thermal cure at $90^{\circ} \mathrm{C}$. Special cares were taken while placing the specimens in the thermal bath and in their removal to avoid thermal shocks. Before the test, the specimens were rectified to improve contact with the plates.

Axial compression tests were performed at a loading speed of $0.45 \mathrm{MPa} / \mathrm{s}$. The determination of the elasticity modulus of the molded concretes in phase 1 was made after the application of three pre-loading cycles, and a strain of $30 \%$ of the breaking strain was adopted for their calculation. This determination was made in three specimens of each composition. In phase 2, the flexural tensile strength test was performed on three points in prismatic specimens $(40 \mathrm{~mm}$ x $40 \mathrm{~mm}$ x $160 \mathrm{~mm}$ ). The test was performed with three points of support and loading speed of $50 \mathrm{~N} / \mathrm{s}$.

\section{RESULTS AND DISCUSSIONS}

\subsection{Compressive strength}

Table 4 presents the results of compressive strength in the three phases of this work.

Table 4. Presents the results of compressive strength in the three phases of this work.

\begin{tabular}{|c|c|c|c|c|c|c|c|c|c|c|c|c|c|c|c|c|}
\hline \multirow{2}{*}{ Compositions } & \multicolumn{8}{|c|}{ Phase 1} & \multicolumn{4}{|c|}{ Phase 2} & \multicolumn{4}{|c|}{ Phase 3} \\
\hline & 1 & 2 & 3 & 4 & 5 & 6 & 7 & 8 & 9 & 10 & 11 & 12 & 13 & 14 & 15 & 16 \\
\hline CP1 & 198.7 & 159.3 & 155.3 & 100.4 & 193.5 & 170.5 & 247.6 & 265.9 & 241.3 & 191.5 & 239.8 & 189.5 & 310.8 & 296.9 & 281.9 & 286.0 \\
\hline CP2 & 192.0 & 160.0 & 122.1 & 101.6 & 189.5 & 165.8 & 252.4 & 257.6 & 244.1 & 227.5 & 207.5 & 237.1 & 309.4 & 266.3 & 302.7 & 292.5 \\
\hline CP3 & 175.0 & 153.3 & 119.8 & 91.9 & 156.3 & 164.5 & 233.7 & 238.1 & 246.2 & 231.0 & 236.3 & 241.1 & 311.8 & 291.1 & 271.3 & 280.7 \\
\hline Average (MPa) & 188.6 & 157.5 & 132.4 & 97.9 & 179.7 & 166.9 & 244.6 & 253.9 & 243.8 & 216.7 & 227.9 & 222.5 & 310.7 & 284.8 & 285.3 & 286.4 \\
\hline $\begin{array}{c}\text { Standard } \\
\text { deviation (MPa) }\end{array}$ & 10.0 & 3.0 & 16.2 & 4.3 & 16.7 & 2.6 & 7.9 & 11.6 & 2.0 & 17.9 & 14.4 & 23.5 & 1.0 & 13.3 & 13.0 & 4.8 \\
\hline $\begin{array}{c}\text { Variation } \\
\text { coefficient (\%) }\end{array}$ & 5.3 & 1.9 & 12.2 & 4.4 & 9.3 & 1.5 & 3.2 & 4.6 & 0.8 & 8.2 & 6.3 & 10.5 & 0.3 & 4.7 & 4.6 & 1.7 \\
\hline
\end{tabular}

In phase 1, the influence of the aggregate particle size in RPC strength was assessed. Results show very consistently that the maximum characteristic dimension of the aggregate impacts, significantly, the RPC compressive strength. Table 5 presents the result of phase 1 compressive strength variance analysis. As described in Table 5 , the probability of the average strengths to belong to the same population is much inferior to $5 \%(p=0.05)$. That is, the maximum characteristic dimension has significant influence in RCP compressive strength, for $95 \%$ reliability.

Table 5. ANOVA - Phase 1, only compositions with 0.25 water/cement ratio - the influence of granular skeleton.

\begin{tabular}{|c|c|c|c|c|c|c|}
\hline Variation source & $S Q$ & $g l$ & $M Q$ & $F$ & value-P & F critical \\
\hline Between groups & 50846.48 & 4 & 12711.62 & 182.17 & $2.69 \mathrm{E}-09$ & 3.48 \\
\hline Within groups & 697.80 & 10 & 69.78 & & & \\
\hline Total & 51544.28 & 14 & & & & \\
\hline
\end{tabular}

Figure 4 present the average results of compressive strength in phase 1 , for $w / c$ ratio of 0.25 . There is a representative reduction of $61 \%$ to RPC axial compression strength when quartz powder with grains passing through the sieve with a mesh opening of $0.045 \mathrm{~mm}$ is replaced by sand with a maximum dimension of $1.2 \mathrm{~mm}$.

De Larrard e Sedran (1994) proposed a model to explain the increase in compressive strength in concretes. According to the authors, the maximum thickness of the pasts (Equation 1) is the second most important factor (the first is the $w / c$ ratio).

$$
e_{M}=D^{*}\left(\sqrt[3]{g^{*} / g}-1\right)
$$




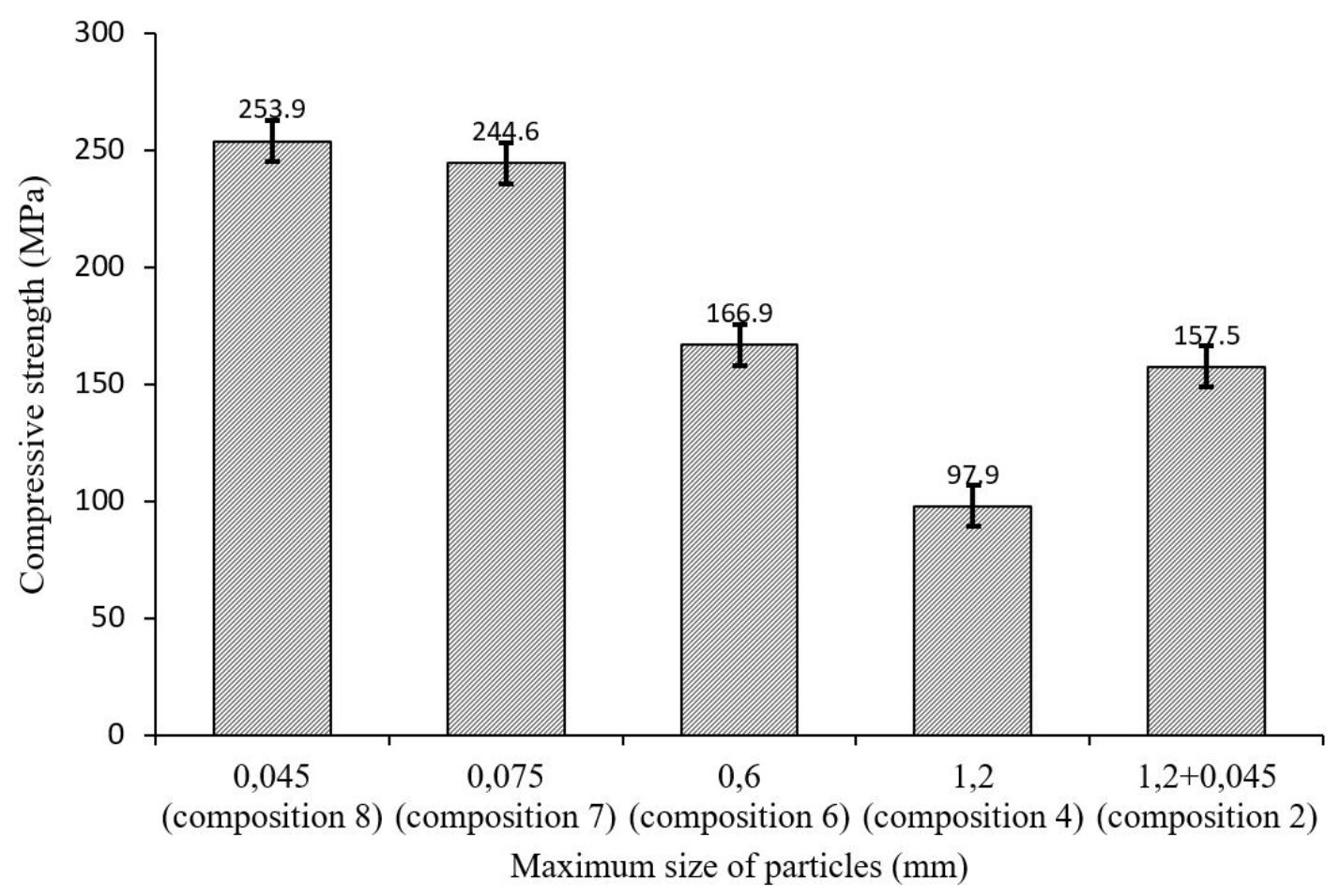

Figure 4. Influence of MAS (Maximum aggregate size) of the aggregate in RPC with $0.25 \mathrm{w} / \mathrm{c}$ ratio - Phase 1.

Where $e_{M}$ is the maximum paste thickness, $D$ is the maximum size of the aggregate, $g *$ is the aggregate packaging density (existing relationships among the volume of solid present in a given unit volume), and $g$ is the total volume of aggregate used per cubic meter of concrete. In Phase 1, the aggregate packaging density and the total volume was not changed, so the paste thickness of the different compositions was change only by the maximum aggregate size $(D)$. The experimental results of this work can be explained by the model proposed by de Larrard and Sedran [16] because the smaller the aggregate grain size, the lower the maximum thickness of the paste. And the more confined is the paste, the higher is the RPC compressive strength. The difference in thickness of the paste of RPC dosed with $0.045 \mathrm{~mm}$ aggregate $\left(e_{M}=0.004416 \mathrm{~mm}\right)$ is more than 25 times smaller than the paste thickness of RPC dosed with $1.2 \mathrm{~mm}$ aggregate $\left(e_{M}=0.117762 \mathrm{~mm}\right)$. These 25 times difference resulted in a $156 \mathrm{MPa}$ increase.

Though being known for quite a long time, the maximum thickness reduction of paste has been used to optimize the RPC differently. Several works use quartz sands with a maximum size of 0.5 and $0.6 \mathrm{~mm}$ [1], [4], [6], [10], [15], [19], [23], 0.8 and $1.0 \mathrm{~mm} \mathrm{[17],} \mathrm{[22],} 3 \mathrm{~mm} \mathrm{[11],} \mathrm{[12],} \mathrm{[21]} \mathrm{and} \mathrm{even} 4 \mathrm{~mm} \mathrm{[3].}$

After the composition with the higher strength was determined, in phase 2, a study was conducted to assess the effect of nanosilica incorporation in the compressive strength. Differently from the maximum size, nanosilica content did not show significant impact in compressive strength. Table 6 shows a summary of the variance analysis made for phase 2, the probability (value-p) of strengths belonging to one single distribution is superior to $0.05(5 \%)$, that is, the content of chemical admixture with nanosilica did not significantly change the RPC compressive strength. Figure 5 shows the average strengths determined in phase 2. Despite that, other works, like that of Han et al. [14], verified a $10.32 \%$ increase in compressive strength while using $5 \%$ of titanium dioxide coated with nanosilica particles in one composition of RPC.

Table 6. ANOVA Phase 2 - the influence of nanosilica content.

\begin{tabular}{|c|c|c|c|c|c|c|}
\hline Variation source & $S Q$ & $g l$ & $M Q$ & $\boldsymbol{F}$ & value-P & $F$ critical \\
\hline Between groups & 1225.78 & 3 & 408.59 & 1.01 & 0.438 & 4.07 \\
\hline Within groups & 3244.44 & 8 & 405.56 & & & \\
\hline Total & 4470.22 & 11 & & & & \\
\hline
\end{tabular}




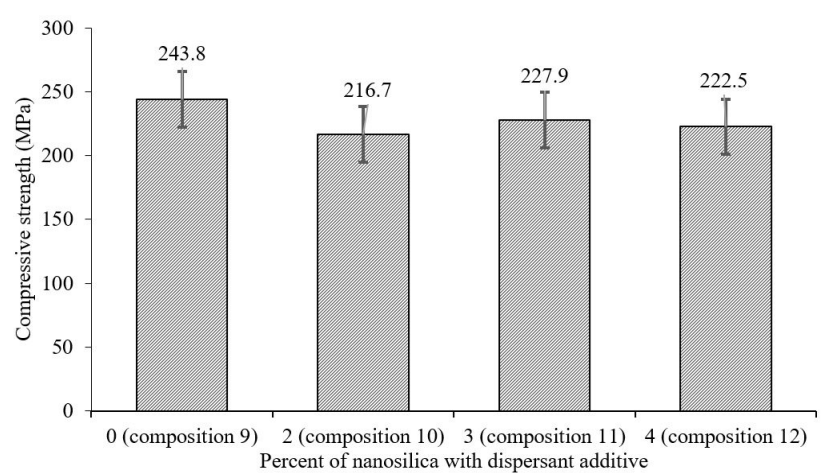

Figure 5. Influence of nanosilica content in powder reactive concrete compressive strength - Phase 2.

The objective of phase 3 was to assess the incorporation of inorganic pigments in the RPC. Similar to phase 2, in phase 3, eight composition of phase 1 was used. To improve the concrete aspect, CP V-ARI (HE PC - high early strength Portland cement) was replaced by CP-B-40. The results of phase 3 can lead us to two conclusions. The first is that there is no significant difference across the different pigments studied in the RPC compressive strength. As can be observed in Table 7, the variation across the averages is not significant for 95\% confidence (value-p is higher than 0.05). Figure 6 presents the average strengths for compositions of phase 3 . The second conclusion is that the pigmented concretes exhibited compressive strength significantly superior to that of the RPC with CPV ARI. The difference in average strength of composition $8(253.9 \mathrm{MPa})$ when compared to the composition $13(310.7 \mathrm{MPa})$ was $56.8 \mathrm{MPa}$, which corresponds to a $22 \%$ increase in strength. The authors understand that the superior fineness (Table 1) of white cement improved the packaging of particles, as well as the larger surface area of the particle, which provides larger contact surface among particle, favoring the formation of hydration products. Another representative factor that contributed to strength increase was the presence of pigment, composed of highly fine particles. According to Richard and Cheyrezy [1], the increase in granular packaging improves RPC mechanical performance.

Among the different RPC research using natural aggregate, without fibers, those that obtained the highest compressive strengths reached strengths superior or close to $300 \mathrm{MPa}$ [1], [3], [11], [12]. However, to surpass the $300 \mathrm{MPa}$ strength, the authors use pre-densification stress like Yazıc1 et al. [11] which get $324 \mathrm{MPa}$, pre-densification stress with autoclave curing like Aydin et al. [3] which get $325 \mathrm{MPa}$. Thus, the results presented in phase 3 of this research are relevant due the high strength achieved without any pre-densification or autoclave curing.

Table 7. ANOVA Phase 3 - influence of the type of pigment in concrete strength

\begin{tabular}{ccccccc}
\hline Variation source & $\boldsymbol{S Q}$ & $\boldsymbol{g l}$ & $\boldsymbol{M Q}$ & $\boldsymbol{F}$ & value-P & $\boldsymbol{F}$ critical \\
\hline Between groups & 1225.78 & 3 & 408.59 & 1.01 & 0.438 \\
\hline Within groups & 3244.44 & 8 & 405.56 & & \\
\hline Total & 4470.22 & 11 & & & \\
\hline
\end{tabular}

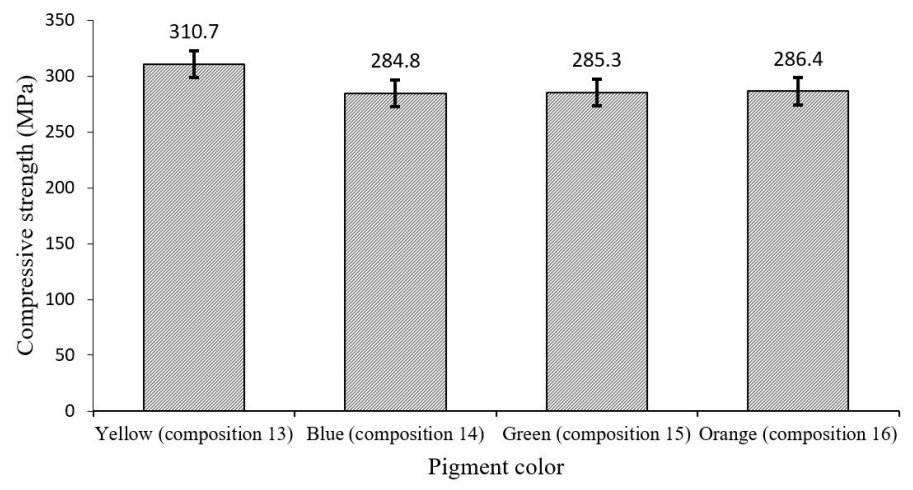

Figure 6. Influence of type of pigment in RCP compressive strength - Phase 3. 


\subsection{Tensile strength}

Figure 7 shows the average values determined for flexural tensile strength. The flexural tensile strength was significantly changed by the incorporation of the superplasticizer containing nanosilica. Table 8 presents a summary of the ANOVA made for phase 2. The probability of having the results determined belonging to one single population is lower than $5 \%$ (value-P lower than 0.05 ).

The difference of composition 9, which does not have nanosilica in its composition, and the other compositions (10; 11; and 12) of phase 2 is outstanding. The presence of nanosilica provided an average increase of $50 \%$. Though there is an increase in flexural tensile strength with an increase in nanosilica content, the difference determined across contents $(2 \% ; 3 \%$ and $4 \%)$ is not significantly different. Han et al. [14] observed an $87 \%$ increase in flexural tensile strength at 28 days in RPC with the incorporation of titanium dioxide coated with nanosilica.

Table 8. ANOVA Phase 2 - the influence of nanosilica content in concrete tensile strength

\begin{tabular}{|c|c|c|c|c|c|c|}
\hline Variation source & $S Q$ & $g l$ & $M Q$ & $F$ & value-P & F critical \\
\hline Between groups & 217.09 & 3 & 72.36 & 6.37 & 0.016272 & 4.07 \\
\hline Within groups & 90.82 & 8 & 11.35 & & & \\
\hline Total & 307.91 & 11 & & & & \\
\hline
\end{tabular}

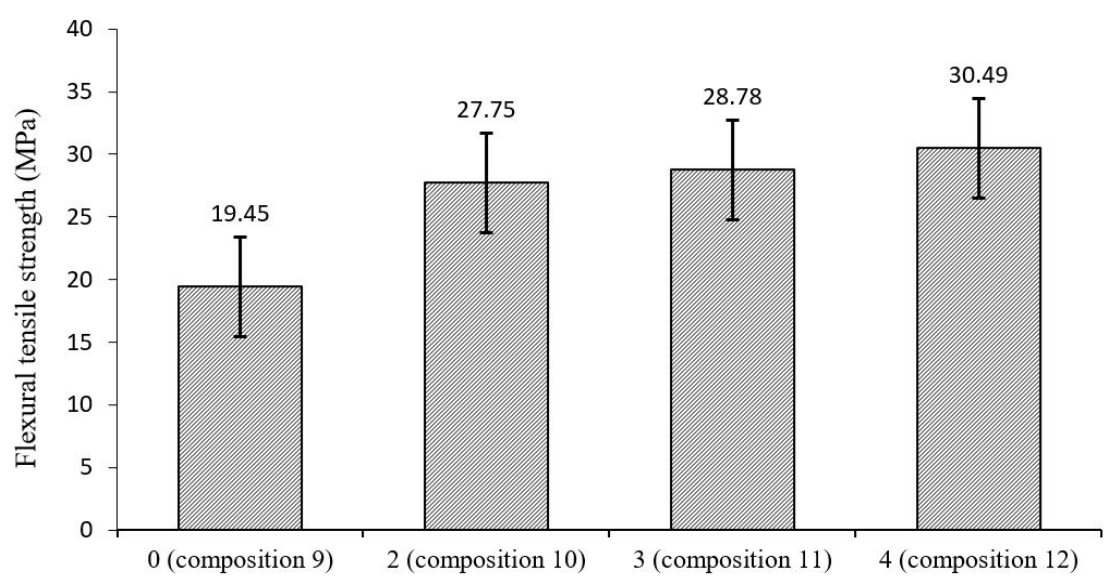

Percent of nanosilica with dispersant additive

Figure 7. Influence of content of nanosilica in the RPC - Phase 2

\subsection{Elasticity modulus}

For concrete compositions determined in phase 1, the elasticity modulus was also determined. Figure 8 shows the average values for phase 1 compositions' modulus of elasticity. The average elasticity modulus of the different compositions was $44.4 \mathrm{GPa}$. These results are slightly inferior to those determined by Richard and Cheyrezy [1], who found values from 50 to $60 \mathrm{GPa}$. However, Vanderlei [2] found similar values (47.3 GPa) analysing RPC without fibers.

The results found in this study demonstrate that the maximum aggregate size did not have a significant influence on the elasticity modulus. Table 9 presents a summary of the variance analysis performed. The probability of having the samples belonging to one single population is superior to $5 \%$ (value-p superior to 0.05 ).

Table 9. ANOVA Phase 1 - the influence of the maximum aggregate size in RPC elasticity modulus

\begin{tabular}{|c|c|c|c|c|c|c|}
\hline Variation source & $S Q$ & $g l$ & $M Q$ & $F$ & value-P & $F$ critical \\
\hline Between groups & 1.77 & 4 & 0.44 & 0.051 & 0.993 & 5.19 \\
\hline Within groups & 43.37 & 5 & 8.67 & & & \\
\hline Total & 45.13 & 9 & & & & \\
\hline
\end{tabular}




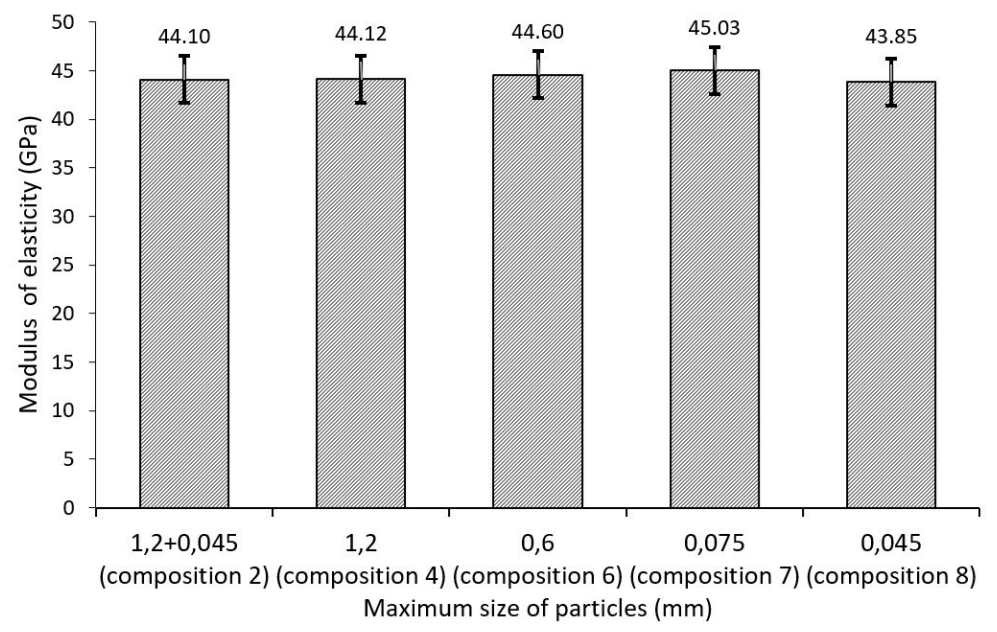

Figure 8. Influence of the maximum aggregate size in RPC elasticity modulus- Phase 1.

\section{CONCLUSIONS}

This work aimed at optimizing the mechanical properties of one RPC composition by choosing the aggregate, incorporating nanosilica and inorganic pigments, to maximize the mechanical performance. The main conclusions are described next:

a) RCP strength can be significantly increased by reducing the maximum size of the aggregate used. While reducing the maximum size of the aggregate from $1.2 \mathrm{~mm}$ to $0.045 \mathrm{~mm}$, the RPC strength increased $156 \mathrm{MPa}(61 \%)$.

b) The maximum size of the aggregate does not significantly change RCP elasticity modulus.

c) The addition of nanosilica starting from $2 \%$ provided an average increase of $50 \%$ in RPC flexural tensile strength. However, a significant change in compressive strength was not observed with the addition of nanosilica.

d) The study showed the possibility of producing a colored RPC with compressive strength superior to 300 MPa only with the thermal cure, without the need of pre-densification procedures or even autoclave curing.

As a suggestion for future works, we recommend the study of RPC with different contents of quartz powder to further reduce the maximum thickness of the paste and understand its influence in RPC properties.

\section{ACKNOWLEDGEMENTS}

The authors would like to acknowledge the infrastructure of the Laboratory of Materials and Technology of the Built Environment (LAMTAC/NORIE) of Federal University of Rio Grande do Sul.

\section{REFERENCES}

[1] P. Richard and M. Cheyrezy, "Composition of reactive power concrete," Cement Concr. Res., vol. 25, no. 7, pp. 1501-1511, 1995, http://dx.doi.org/10.1016/0008-8846(95)00144-2.

[2] R. D. Vanderlei, “Análise experimental do concreto de pós reativos: dosagem e propriedades mecânicas," Ph.D. dissertation, Esc. Eng. São Carlos, Univ. São Paulo, São Paulo, 2004.

[3] S. Aydin, H. Yazici, M. Y. Yardimci, and H. Yigiter, "Effect of aggregate type on mechanical properties of reactive powder concrete," ACI Mater. J., vol. 107, no. 5, pp. 441-449, 2010, http://dx.doi.org/10.14359/51663963.

[4] G. Long, X. Wang, and Y. Xie, "Very-high-performance concrete with ultrafine powders," Cement Concr. Res., vol. 32, no. 1, pp. 601-605, 2001, http://dx.doi.org/10.1016/S0008-8846(01)00732-3.

[5] Z. Yunsheng, S. Wei, L. Sifeng, J. Chujie, and L. Jianzhong, "Preparation of C200 green reactive powder concrete and its staticdynamic behaviors," Concr. Concr. Compos., vol. 30, no. 9, pp. 831-838, 2008, http://dx.doi.org/10.1016/j.cemconcomp.2008.06.008.

[6] M. Jinchuan, O. Zhongwen, Z. Xuxin, L. Jinming, and W. Yahui, "Influence of superabsorbent polymer on shrinkage properties of reactive powder concrete blended with granulated blast furnace slag," Constr. Build. Mater., vol. 146, no. 1, pp. 283-296, 2017, http://dx.doi.org/10.1016/j.conbuildmat.2017.04.105. 
[7] W. Kushartomo, I. Bali, and B. Sulaiman, "Mechanical behavior of reactive powder concrete with glass powder substitute," Procedia Eng., vol. 125, no. 1, pp. 617-622, 2015, http://dx.doi.org/10.1016/j.proeng.2015.11.082.

[8] P. Zhu, X. Mao, W. Qu, Z. Li, and Z. J. Ma, "Investigation of using recycled powder waste of clay bricks and cement solids in reactive powder concrete," Constr. Build. Mater., vol. 113, no. 1, pp. 246-254, 2016, http://dx.doi.org/10.1016/j.conbuildmat.2016.03.040.

[9] P. Yanzhou, Z. Jun, L. Jiuyan, K. Jin, and W. Fazhou, "Properties and microstructure of reactive powder concrete having a high content of phosphorous slag powder and silica fume," Constr. Build. Mater., vol. 101, no. 1, pp. 482-487, 2015, http://dx.doi.org/10.1016/j.conbuildmat.2015.10.046.

[10] S. Ahmad, A. Zubair, and M. Maslehuddin, "Effect of key mixture parameters on flow and mechanical properties of reactive powder concrete," Constr. Build. Mater., vol. 99, no. 1, pp. 73-81, 2015., http://dx.doi.org/10.1016/j.conbuildmat.2015.09.010.

[11] H. Yazıc1, H. Yigiter, A. Karabulut, and B. Baradan, "Utilization of fly ash and ground granulated blast furnace slag as an alternative silica source in reactive powder concrete," Fuel, vol. 87, no. 1, pp. 2401-2407, 2008., http://dx.doi.org/10.1016/j.fuel.2008.03.005.

[12] H. Yazici, M. Y. Yardimci, S. Aydin, and A. S. Karabulut, "Mechanical properties of reactive powder concrete containing mineral admixtures under different curing regimes," Constr. Build. Mater., vol. 23, no. 3, pp. 1223-1231, 2009., http://dx.doi.org/10.1016/j.conbuildmat.2008.08.003.

[13] H. Yiğiter, S. Aydin, H. Yazici, and M. Y. Yardimci, "Mechanical performance of low cement reactive powder concrete (LCRPC)," Compos., Part B Eng., vol. 43, no. 8, pp. 2907-2914, 2012., http://dx.doi.org/10.1016/j.compositesb.2012.07.042.

[14] B. Han et al., "Reactive powder concrete reinforced with nano $\mathrm{SiO}_{2}$-coated $\mathrm{TiO}_{2}$," Constr. Build. Mater., vol. 148, no. 1, pp. 104112, 2017., http://dx.doi.org/10.1016/j.conbuildmat.2017.05.065.

[15] P. N. Hiremath and S. C. Yaragal, "Influence of mixing method, speed and duration on the fresh and hardened properties of Reactive Powder Concrete," Constr. Build. Mater., vol. 141, no. 1, pp. 271-288, 2017., http://dx.doi.org/10.1016/j.conbuildmat.2017.03.009.

[16] F. de Larrard and T. Sedran, "Optimization of ultra-high-performance concrete by the use of a packing model," Cement Concr. Res., vol. 24, no. 6, pp. 997-1009, 1994., http://dx.doi.org/10.1016/0008-8846(94)90022-1.

[17] B. Han et al., "Microstructure related mechanical behaviors of short-cut super-fine stainless wire reinforced reactive powder concrete," Mater. Des., vol. 96, no. 1, pp. 16-26, 2016., http://dx.doi.org/10.1016/j.matdes.2016.02.004.

[18] T. Ji, C. Chen, and Y. Z. Zhuang, "Evaluation method for cracking for cracking resistant behavior of reactive powder concrete," Constr. Build. Mater., vol. 28, no. 1, pp. 45-49, 2012., http://dx.doi.org/10.1016/j.conbuildmat.2011.08.060.

[19] M. Ipek, K. Yilmaz, M. Sümer, and M. Saribiyik, "Effect of pre-setting pressure applied to mechanical behaviors of reactive powder concrete during setting phase," Constr. Build. Mater., vol. 25, no. 1, pp. 61-68, 2011., http://dx.doi.org/10.1016/j.conbuildmat.2010.06.056.

[20] M. Ipek, K. Yilmaz, and M. Uysal, "The effect of pre-setting pressure applied flexural strength and fracture toughness of reactive powder concrete during the setting phase," Constr. Build. Mater., vol. 26, no. 1, pp. 459-465, 2012., http://dx.doi.org/10.1016/j.conbuildmat.2011.06.045.

[21] H. Yazıc1, E. Deniz, and B. Baradan, "The effect of autoclave pressure, temperature and duration time on mechanical properties of reactive powder concrete," Constr. Build. Mater., vol. 42, no. 1, pp. 53-63, 2013., http://dx.doi.org/10.1016/j.conbuildmat.2013.01.003.

[22] D. Mostofinejad, M. R. Nikoo, and S. A. Hosseini, "Determination of optimized mix design and curing conditions of reactive powder concrete (RPC)," Constr. Build. Mater., vol. 123, no. 1, pp. 754-767, 2016., http://dx.doi.org/10.1016/j.conbuildmat.2016.07.082.

[23] T. Zerb, "An analysis of the steam curing and autoclaving process parameters for reactive powder concrete," Constr. Build. Mater., vol. 131, no. 1, pp. 758-766, 2017, http://dx.doi.org/10.1016/j.conbuildmat.2016.11.026.

[24] L. Huynh, S. Foster, H. Valipour, and R. Randall, "High strength and reactive powder concrete columns subjected to impact: Experimental investigation," Constr. Build. Mater., vol. 78, no. 1, pp. 153-171, 2015., http://dx.doi.org/10.1016/j.conbuildmat.2015.01.026.

[25] C. Y. Ni, H. Y. Xia, Q. C. Zhang, W. B. Wang, and Z. H. L. U. Cheng, "Perforation resistance of corrugated metallic sandwich plates filled with reactive powder concrete: experiment and simulation," Compos. Struct., vol. 127, no. 1, pp. 426-435, 2015., http://dx.doi.org/10.1016/j.compstruct.2015.02.059.

[26] V. Matte and M. Moranville, "Durability of reactive powder composites: influence of silica fume on the leaching properties of very low water/binder pastes," Cement Concr. Compos., vol. 21, no. 1, pp. 1-9, 1999., http://dx.doi.org/10.1016/S0958-9465(98)00025-0.

[27] Associação Brasileira de Normas Técnicas, NM 43, 2002.

[28] Associação Brasileira de Normas Técnicas, NBR 7681, 2013.

[29] American Society for Testing and Materials, ASTM C939, 2002. 
[30] S. Formagini, "Dosagem cientifica e caracterização mecânica de concretos de altíssimo desempenho," Ph.D. dissertation, Rio de Janeiro, Univ. Fed. Rio de Janeiro, 2005.

Author contributions: Contribution description of each co-author for the study. Denise Dal Molin: conceptualization, funding acquisition, supervision, writing; Abrahão Bernardo Rohden: conceptualization, data curation, formal analysis, methodology, writing; Ana Paula Kirchheim: data curation, formal analysis.

Editors: Bernardo Tutikian, José Luiz Antunes de Oliveira e Sousa, Guilherme Aris Parsekian. 